\title{
Adenosine Enhances Sweet Taste through A2B Receptors in the Taste Bud
}

\author{
Robin Dando, ${ }^{1 \star}$ Gennady Dvoryanchikov, ${ }^{1 \star}$ Elizabeth Pereira, ${ }^{1}$ Nirupa Chaudhari, ${ }^{1,2}$ and Stephen D. Roper ${ }^{1,2}$ \\ ${ }^{1}$ Department of Physiology and Biophysics and ${ }^{2}$ Program in Neuroscience, Miller School of Medicine, University of Miami, Miami, Florida 33136
}

Mammalian taste buds use ATP as a neurotransmitter. Taste Receptor (type II) cells secrete ATP via gap junction hemichannels into the narrow extracellular spaces within a taste bud. This ATP excites primary sensory afferent fibers and also stimulates neighboring taste bud cells. Here we show that extracellular ATP is enzymatically degraded to adenosine within mouse vallate taste buds and that this nucleoside acts as an autocrine neuromodulator to selectively enhance sweet taste. In Receptor cells in a lingual slice preparation, $\mathrm{Ca}^{2+}$ mobilization evoked by focally applied artificial sweeteners was significantly enhanced by adenosine (50 $\mu \mathrm{M})$. Adenosine had no effect on bitter or umami taste responses, and the nucleoside did not affect Presynaptic (type III) taste cells. We also used biosensor cells to measure transmitter release from isolated taste buds. Adenosine $(5 \mu \mathrm{M})$ enhanced ATP release evoked by sweet but not bitter taste stimuli. Using single-cell reverse transcriptase (RT)-PCR on isolated vallate taste cells, we show that many Receptor cells express the adenosine receptor, Adora2b, while Presynaptic (type III) and Glial-like (type I) cells seldom do. Furthermore, Adora2b receptors are significantly associated with expression of the sweet taste receptor subunit, Tas1r2. Adenosine is generated during taste stimulation mainly by the action of the ecto-5' -nucleotidase, NT5E, and to a lesser extent, prostatic acid phosphatase. Both these ecto-nucleotidases are expressed by Presynaptic cells, as shown by single-cell RT-PCR, enzyme histochemistry, and immunofluorescence. Our findings suggest that ATP released during taste reception is degraded to adenosine to exert positive modulation particularly on sweet taste.

\section{Introduction}

A number of neurotransmitters play a role in shaping the final signal output from taste buds, including ATP (Finger et al., 2005), serotonin (Huang et al., 2005), norepinephrine (Herness et al., 2002), glutamate (Vandenbeuch et al., 2010), GABA (Dvoryanchikov et al., 2011), and acetylcholine (Ogura, 2002), as well as a number of peptide neuromodulators (Kawai et al., 2000; Shin et al., 2008). Specifically, ATP is a key afferent neurotransmitter for taste cells (Finger et al., 2005). Taste receptor cells secrete ATP onto afferent fibers at sites of close apposition between cells and axons, instead of at well demarcated synapses. ATP is released via pannexin 1 gap junction hemichannels and is believed to diffuse to adjacent afferent terminals where it stimulates $\mathrm{P} 2 \mathrm{X}$ receptors on the sensory fibers (Finger et al., 2005; Huang et al., 2007; Romanov et al., 2007). The spread of ATP is limited by an ectoATPase, nucleoside triphosphate diphosphohydrolase 2 (NTPDase2), that is expressed by glial-like type I taste cells (Bartel et al., 2006). Lamellar processes from type I cells ensheath other cells

Received Aug. 8, 2011; revised Oct. 7, 2011; accepted Nov. 3, 2011.

Author contributions: R.D., G.D., E.P., N.C., and S.D.R. designed research; R.D., G.D., and E.P. performed research; R.D., G.D., E.P., N.C., and S.D.R. analyzed data; R.D., G.D., N.C., and S.D.R. wrote the paper.

This research was supported by NIH Grants 2R01DC007630 and 5R01DC000374 to S.D.R. and R01DC006021 and R01DC006308 to N.C. We thank Drs. M. Zylka and L. Thompson who generously provided tissue from genetic knock-out mice, and Dr. Y. J. Huang for maintaining cell cultures.

${ }^{*}$ R.D. and G.D. contributed equally.

The authors declare there no competing financial interests.

Correspondence should be addressed to either Stephen D. Roper or Nirupa Chaudhari, Department of Physiology and Biophysics, University of Miami, Leonard M. Miller School of Medicine, P.0. Box 016430, Miami, FL 33101, E-mail: sroper@med.miami.edu or nchaudhari@med.miami.edu.

DOI:10.1523/JNEUROSCI.4070-11.2012

Copyright $\odot 2012$ the authors $\quad 0270-6474 / 12 / 320322-09 \$ 15.00 / 0$ within the taste bud, further restricting the spread of ATP throughout the taste bud (Pumplin et al., 1997; Dando and Roper, 2009).

In many tissues that use ATP as a transmitter, ATP is degraded by NTPDases, nucleotide pyrophosphatases, and acidic or alkaline phosphatases to produce adenosine and its monophosphates or diphosphates (Kukulski et al., 2011). These adenosine derivatives have additional actions as autocrine and paracrine modulators. For instance, in taste buds, ADP generated by NTPDase 2 exerts positive autocrine feedback onto taste cells during gustatory stimulation (Huang et al., 2009). Moreover, adenosine itself is a widespread modulator of neurotransmitter release in the central and enteric nervous systems (Christofi, 2008; Sperlágh and Vizi, 2011). Importantly for the present work, a recent preliminary report implicates adenosine signaling particularly for sweet taste (Kinnamon et al., 2011).

Thus, we have undertaken a study to examine whether and how adenosine might be formed in taste buds during taste stimulation and if this nucleoside might have some effect on taste bud cells. Our findings indicate that adenosine, acting through $\mathrm{A} 2 \mathrm{~B}$ receptors, increases sweet-evoked responses in taste receptor cells and enhances taste transmitter release from these cells. These effects are specific for sweet taste and are not observed with bitter or umami taste stimuli.

\section{Materials and Methods}

Animals. All experimental procedures were approved by the University of Miami Animal Care and Use Committee. Animals of both sexes were killed via exposure to $\mathrm{CO}_{2}$ followed by cervical dislocation. The lines of mice used in these experiments included C57BL/6 mice (wild-type); mice expressing GFP under the control of the PLC $\beta 2$ (Kim et al., 2006) or Gad1 (Chattopadhyaya et al., 2004) promoters, used to identify Receptor 
Table 1. Oligonucleotide primers used in RT-PCR

\begin{tabular}{|c|c|c|c|c|c|}
\hline Protein/gene & Accession number & Forward primer $\left(5^{\prime} \rightarrow 3^{\prime}\right)$ & Reverse primer $\left(5^{\prime} \rightarrow 3^{\prime}\right)$ & Product (bp) & Annealing temperature $\left({ }^{\circ} \mathrm{C}\right)$ \\
\hline NTPDase2/Entpd2 & NM_009849 & agctggaggatgccacagag & gagagcaacccaggagctga & 299 & 63 \\
\hline $\operatorname{PLC} \beta 2 / P / c b 2$ & NM_177568 & gagcaaatcgccaagatgat & ccttgtctgtggtgaccttg & 163 & 60 \\
\hline SNAP25/Snap25 & NM_011428 & ggcaataatcaggatggagtag & agatttaaccacttcccagca & 310 & 58 \\
\hline T1R1/Tas1r1 & NM_031867 & ctggaatggacctgaatggac & agcagcagtggtgggaac & 185 & 60 \\
\hline T1R2/Tas1r2 & NM_031873 & aagcatcgectectactcc & ggctggcaactcttagaacac & 114 & 58 \\
\hline $\mathrm{T} 1 \mathrm{R} 3 / \operatorname{Tas} 1 \mathrm{r3}$ & NM_031872 & gaagcatccagatgacttca & gggaacagaaggacactgag & 283 & 58 \\
\hline T2R5/Tas2r105 & NM_020501 & gaatcatagaaacaggacctcg & ctttacaaaggcttgctttagc & 406 & 57 \\
\hline T2R8/Tas2r108 & NM_020502 & ttctgatttcagecctcacc & ccaaaagctggtcctgtttc & 245 & 60 \\
\hline A1/Adora 1 & NM_001008533 & atccctctccggtacaagacagt & actcaggttgttccagccaaac & 120 & 60 \\
\hline A2A/Adora $2 a$ & NM_009630 & ccgaattccactccggtaca & cagttgttccageccagcat & 120 & 60 \\
\hline $\mathrm{A} 2 \mathrm{~B} /$ Adora $2 b$ & NM_007413 & tcttcctcgectgcttcgt & ccagtgaccaaacctttatacctga & 121 & 60 \\
\hline A3/Adora3 & NM_009631 & acttctatgcctgccttttcatgt & aaccgttctatatctgactgtcagctt & 128 & 60 \\
\hline NT5E, CD73/Nt5e & NM_011851 & ggaatccatgtggtgtacg & gaaagcttccctggtaatg & 317 & 60 \\
\hline ACPP, $\mathrm{PAP} / A c p p$ & NM_207668 & cagccacgtttgtaatggaa & aaaaggctgtcatcgaatgg & 258 & 58 \\
\hline
\end{tabular}

(type II) and Presynaptic (type III) taste cells, respectively (DeFazio et al., 2006; Tomchik et al., 2007); and Plcb2-GFP/Gad1-GFP double transgenic mice in which GFP-negative cells represent predominantly type I cells (Dvoryanchikov et al., 2009). We also examined taste buds in mice with a genetic deletion of ecto- $5^{\prime}$-nucleotidase $\left(N t 5 e^{-1-}\right)$ (Thompson et al., 2004). Tissues and mice of the $N t 5 e^{-1-}$ strain were courtesy of Dr. M. Zylka, University of North Carolina, Chapel Hill, NC, and Dr. L. Thompson, Oklahoma Medical Research Foundation, Oklahoma City, OK.

Taste bud isolation. Lingual epithelium was peeled from the circumvallate papillae, incubated in Tyrode's buffer, and whole taste buds were collected with a fire-polished micropipette (Huang et al., 2007; Dvoryanchikov et al., 2009). Taste buds were transferred to a shallow recording chamber, secured with Cell-Tak (BD Biosciences), and superfused with normal Tyrode's solution.

Cellular biosensor technique. CHO cells expressing P2X2 and P2X3 ATP receptors (Huang et al., 2007) were loaded with $5 \mu \mathrm{M}$ FURA-2-AM, and screened for sensitivity. Images were acquired ratiometrically using Fura-2 optics, and an Olympus IX71 inverted fluorescence microscope with a $20 \times$ water-immersion objective. Imaging analysis was performed using Imaging Workbench 6.0 (INDEC BioSystems), with F340/F380 converted to $\left[\mathrm{Ca}^{2+}\right]$ as described by Grynkiewicz et al. (1985).

Lingual slice preparation and imaging. Lingual slices $(100 \mu \mathrm{m})$ of circumvallate papillae taste buds iontophoretically loaded with $\mathrm{Ca}^{2+}$-sensitive dye (Calcium Green Dextran, 10,000 MW) were imaged in elevated $\mathrm{Ca}^{2+}$ Tyrode's buffer $(8 \mathrm{~mm})$, perfused at $2 \mathrm{ml} / \mathrm{min}$ with taste stimuli applied to the apical tips of taste buds with a focal "puffer" pipette for $2 \mathrm{~s}$ (Dando and Roper, 2009). Images were taken every $2 \mathrm{~s}$, and results are presented as relative fluorescence: $\left.\Delta F / F\left[\left(F-F_{0}\right)\right] / F_{0}\right)$. Photobleaching was corrected, and criteria applied to ensure responses were repeatable, robust, and specific, with stimuli applied $>2$ min apart to prevent desensitization (Caicedo et al., 2000).

Reverse transcriptase-PCR and single-cell expression profiling. Taste buds and individual taste cells from the circumvallate papillae of wildtype, Plcb2-GFP, Gad1-GFP, and double transgenic mice were isolated. Individual taste cells were collected in 16- $\mu \mathrm{m}$-diameter glass pipettes and expelled into $50 \mu \mathrm{l}$ of lysis buffer (Stratagene) containing $200 \mathrm{ng}$ of polyinosinic acid to reduce loss of low copy mRNAs. Total RNA was extracted with DNase I digestion (Nanoprep kit, Stratagene) and converted to cDNA with SuperScript III (Invitrogen). For single-cell reverse transcriptase (RT)-PCR, 20\% of each cell's cDNA was used for Tas1r2, Tas2r105, Tas2r108, and Adora2b, respectively. PCR was performed in $20 \mu \mathrm{l}$ for 45 cycles in parallel with control samples. For a subsequent experiment that probed many additional genes, the cDNA from each cell was subjected to T7 linear RNA amplification using a Message BOOSTER cDNA kit for quantitative PCR (Epicentre) as described previously (Dvoryanchikov et al., 2009).

All PCR primers were intron-spanning (except those for Tas2r105 and Tas2r108) and were designed using Primer3 software. In the case of adenosine receptors, we used previously validated primers (Streitová et al., 2010). All primers are listed in Table 1. RT-PCR was performed with Taq Polymerase (Qiagen) at experimentally determined optimal annealing temperature.
Enzyme histochemistry. The activity of enzymes that degrade AMP to adenosine within tissue was visualized using a modification of thiamine monophosphate histochemistry (Zylka et al., 2008; Sowa et al., 2010). To distinguish between ecto- $5^{\prime}$-nucleotidase (NT5E, a neutral ectonucleotidase) and prostatic acid phosphatase (ACPP, also known as PAP), we performed histochemistry in $0.04 \mathrm{M}$ Tris-maleate buffer at $\mathrm{pH} 7.0$ and 5.6 in parallel (Sowa et al., 2010). In brief, tissue fixed in $4 \%$ paraformaldehyde was cryosectioned at $25 \mu \mathrm{m}$. Sections were adhered to glass slides by drying for 10-15 min., and then rehydrated in Tris-maleate buffer. The enzymatic reaction was performed at $37^{\circ} \mathrm{C}$ for $1-2 \mathrm{~h}$ in Tris-maleate buffer containing $8 \%$ sucrose, $2.4 \mathrm{~mm} \mathrm{~Pb}\left(\mathrm{NO}_{3}\right)_{2}$ and $6 \mathrm{~mm}$ AMP. The lead phosphate product was converted to a brown precipitate by washing for $10 \mathrm{~s}$ in $1 \% \mathrm{Na}_{2} \mathrm{~S}$ in Tris-maleate, after which the slides were washed and mounted. Imaging was performed on a Zeiss Axiophot microscope with Axiocam MRm camera.

Immunofluorescence. Wild-type, $N t 5 e^{-1-}$, and Gad1-GFP mice were perfused with $4 \%$ paraformaldehyde and cryosectioned at $25 \mu \mathrm{m}$ as previously described (Dvoryanchikov et al., 2009). Immunofluorescence for NT5E used 1:100 sheep anti-5' -nucleotidase antibody (AF4488, R\&D Systems) followed by 1:1000 donkey anti-sheep IgG-Alexa Fluor 568 (A-21099, Invitrogen).

Reagents and solutions. Unless otherwise indicated, chemicals were purchased from Sigma. Tyrode's buffer contained the following (in mM): 145 $\mathrm{NaCl}, 5 \mathrm{KCl}, 2 \mathrm{CaCl}_{2}, 1 \mathrm{MgCl}_{2}, 10$ HEPES, 10 glucose, 10 sodium pyruvate, $5 \mathrm{NaHCO}_{3}$. For confocal calcium imaging, an equimolar substitution of calcium for sodium was made to elevate calcium to $8 \mathrm{~mm}$ to enhance responses and improve the signal-to-noise ratio (Caicedo et al., 2000). Similarly, high-K Tyrode's buffer for depolarizing taste cells was made by an equimolar substitution of $50 \mathrm{~mm} \mathrm{KCl}$ for $\mathrm{NaCl}$. Taste stimuli used in these experiments consisted of the following. The "sweet" stimulus was a mixture of synthetic sweeteners, $100 \mu \mathrm{M}$ SC45647 (2-[[[4-(aminomethyl)anilino][[(1R)-1-phenylethyl ]amino]methyl] amino]ethane-1,1-diol) (gift from Dr. G. Dubois, Coca Cola, Atlanta, GA), and 2 mm saccharin. "Umami" (used for focal stimulation of the taste pore in lingual slice preparations only) was a combination of $200 \mathrm{~mm}$ monopotassium glutamate and $1 \mathrm{~mm}$ inosine monophosphate. "Bitter" was a mixture of $30 \mu \mathrm{M}$ cycloheximide and $200 \mu \mathrm{M}$ denatonium. In experiments using confocal imaging on a lingual slice, focally stimulated, fluorescein $(2 \mu \mathrm{M})$ was added to the tastant mixtures to track stimulation and to ensure consistent application from trial to trial.

\section{Results}

\section{Adenosine modulates the taste-evoked responses of taste buds}

Kataoka and Finger (2008) and Kinnamon et al. (2011) reported preliminary findings that taste buds have A2B adenosine receptors and that mice lacking $\mathrm{A} 2 \mathrm{~B}$ receptors have reduced taste afferent neural responses to sucrose and synthetic sweeteners, implicating a role for adenosine in taste reception, particularly for sweet. To examine how adenosine plays a role at the level of the taste bud, we recorded taste-evoked responses from identified Recep- 
tor and Presynaptic taste cells in lingual slices (Fig. $1 A$ ) as previously described (Caicedo et al., 2000; Dando and Roper, 2009). Stimulus-evoked responses were highly repeatable and robust as long as sufficient recovery time was allowed to avoid desensitization. After bath-applying adenosine $(50 \mu \mathrm{M})$, responses in Receptor (type II) cells to a mixture of sweet compounds were significantly enhanced (Fig. $1 B, C$ ). Responses to bitter or umami compounds were unaffected by adenosine, and adenosine itself did not produce a response (Fig. $1 D-G)$. In sour-sensing Presynaptic (type III) taste cells, adenosine did not affect responses evoked by depolarization with $\mathrm{KCl}$ (50 mM, data not shown).

Adenosine modulates neurotransmitter secretion from the taste bud

To further characterize the effect of adenosine in taste buds, we assayed taste-evoked transmitter secretion in the presence and absence of adenosine $(5 \mu \mathrm{M})$. ATP biosensors were used to monitor the release of the afferent transmitter, ATP (Huang et al., 2007). ATP secretion elicited by sweet taste was markedly enhanced by adenosine (Fig. $2 A, B)$, consistent with the effects of adenosine on sweet-evoked Receptor cell responses (Fig. 1 B, C). Conversely, MRS 1706 (250 nM), an antagonist at adenosine A2B receptors, on its own reduced sweet-evoked ATP secretion (Fig. 2C,D), suggesting that there is endogenous positive feedback (autocrine) involving adenosine during sweet taste reception. Bitter-evoked ATP release was unaffected by adenosine or MRS 1706 (Fig. $2 E-H$ ), and ATP release was not stimulated by adenosine alone. Parenthetically, stimulating isolated taste buds with umami compounds is problematic, as bath-applied glutamate is known to stimulate synaptic or extrasynaptic non-taste receptors on taste buds (Caicedo et al., 2000; Vandenbeuch et al., 2010). Thus, we did not test the actions of adenosine on umami-evoked transmitter release. Nevertheless, the lack of adenosinemediated modulation of umami responses in the slice preparation (Fig. $1 F, G$ ) suggests that the nucleoside also has no effect on umami-evoked release of transmitter.

Adenosine is produced locally in taste buds

The above results, specifically the actions of the $\mathrm{A} 2 \mathrm{~B}$ receptor antagonist (Fig. $2 C, D)$, imply that adenosine acts endogenously as a neuromodulator in taste buds. In many tissues, adenosine is generated from AMP (itself a degradation product of ATP) principally by ecto-5'-nucleotidase (NT5E, also known as CD73), or by ACPP
A

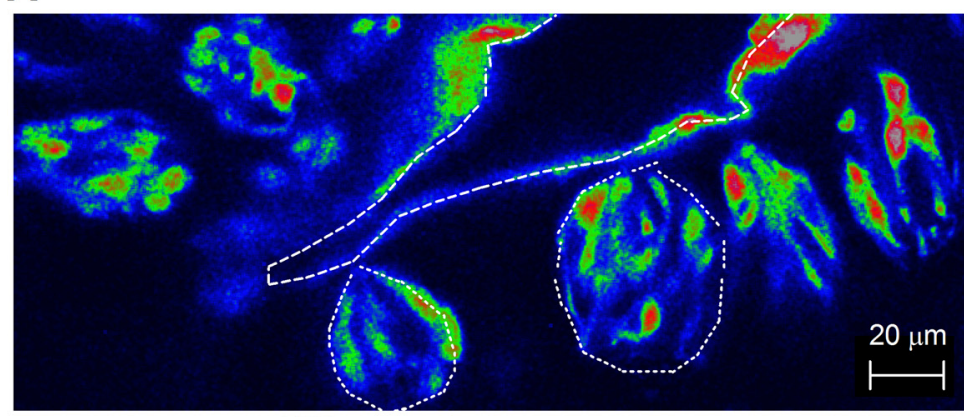

ADO
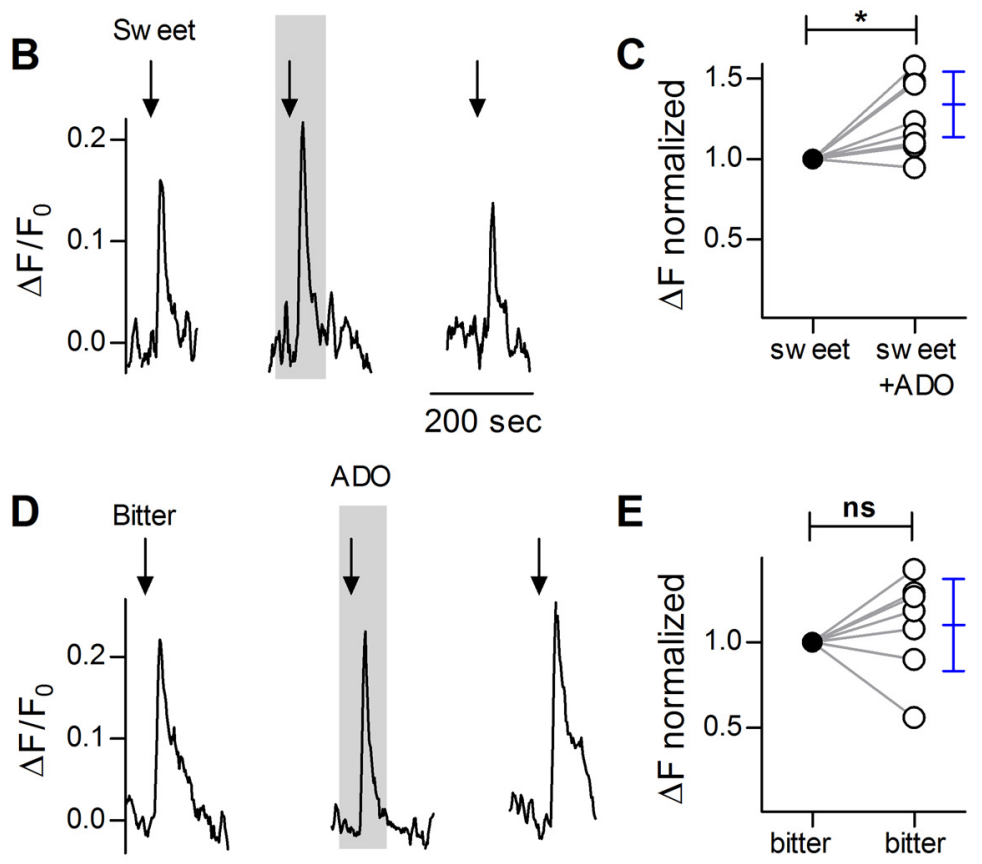

E
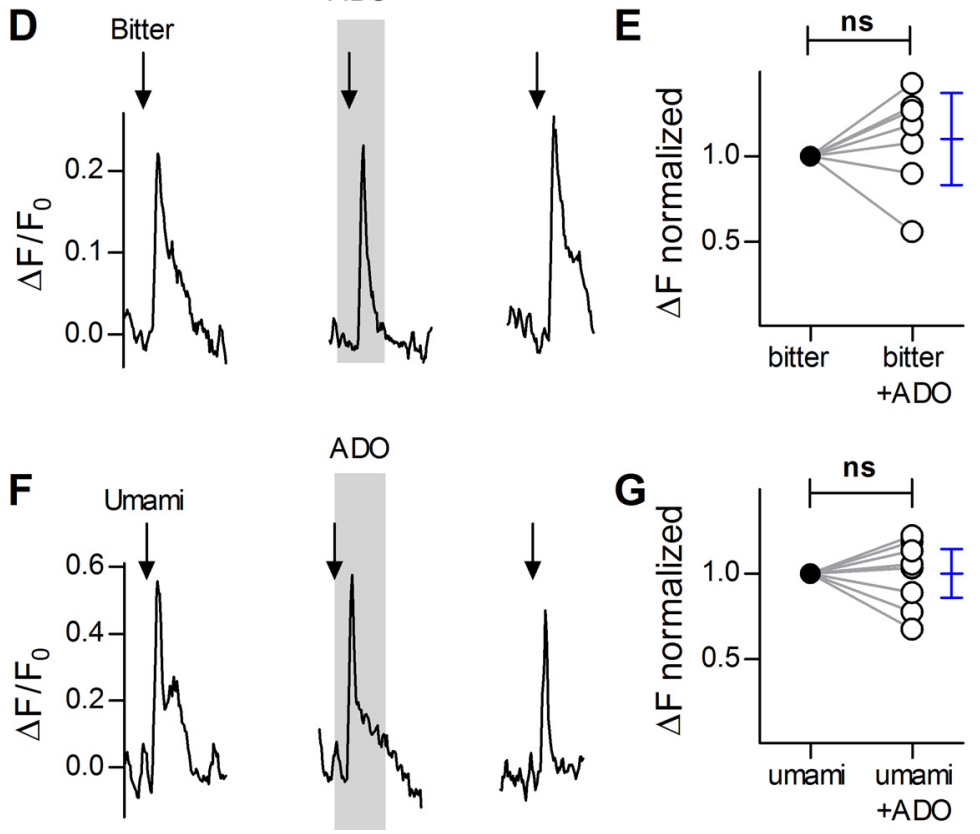

Figure 1. Confocal imaging in lingual slices of taste cells responding to sweet, bitter and umami tastants. $\boldsymbol{A}$, Micrograph of a lingual slice containing a vallate papilla, showing taste cells loaded with calcium green dextran (CaG dextran). Dashed line outlines the vallate crypt along which are embedded the taste buds (two examples outlined with dotted lines). $\boldsymbol{B}$, Stimulation (arrows) of identified Receptor (type II) taste cell with mixture of sweet compounds SC45647 and saccharin, produces $\mathrm{Ca}^{2+}$ responses that are enhanced by the presence of adenosine (50 $\mu \mathrm{m}$, present throughout the shaded area). Note that adenosine itself does not elicit a response. Ordinate, increase in CaG dextran fluorescence relative to baseline (see Materials and Methods). $\boldsymbol{C}$, Summary of data from experiments as in $\boldsymbol{B}$. The plot shows magnitude of responses to sweet stimulation before (filled circles) and during the presence of adenosine (open circles). Responses of each cell were normalized to its responses in the absence of adenosine. Student's $t$ test, two tailed, repeated measures, $p<0.02 . n=8$ cells. Blue symbols show the mean and $95 \%$ confidence interval. $\boldsymbol{D}, \mathrm{Ca}^{2+}$ responses in vallate taste cells stimulated with a bitter taste mix (arrows) in absence or presence (shaded area) of adenosine as in $\boldsymbol{B}$. $\boldsymbol{E}$, Summary of results as in $D$, showing that adenosine does not affect bitter-evoked responses, $p=0.40, n=7$ cells. $\boldsymbol{F}$, As in $\boldsymbol{B}$, showing $\mathrm{Ca}^{2+}$ responses to umami stimulation. $\mathbf{G}$, Summary of data showing that umami-evoked responses are unaffected by adenosine, $p=1.00$, $n=9$ cells. Calibrations in $\boldsymbol{D}$ and $\boldsymbol{F}$ as in $\boldsymbol{B}$. 

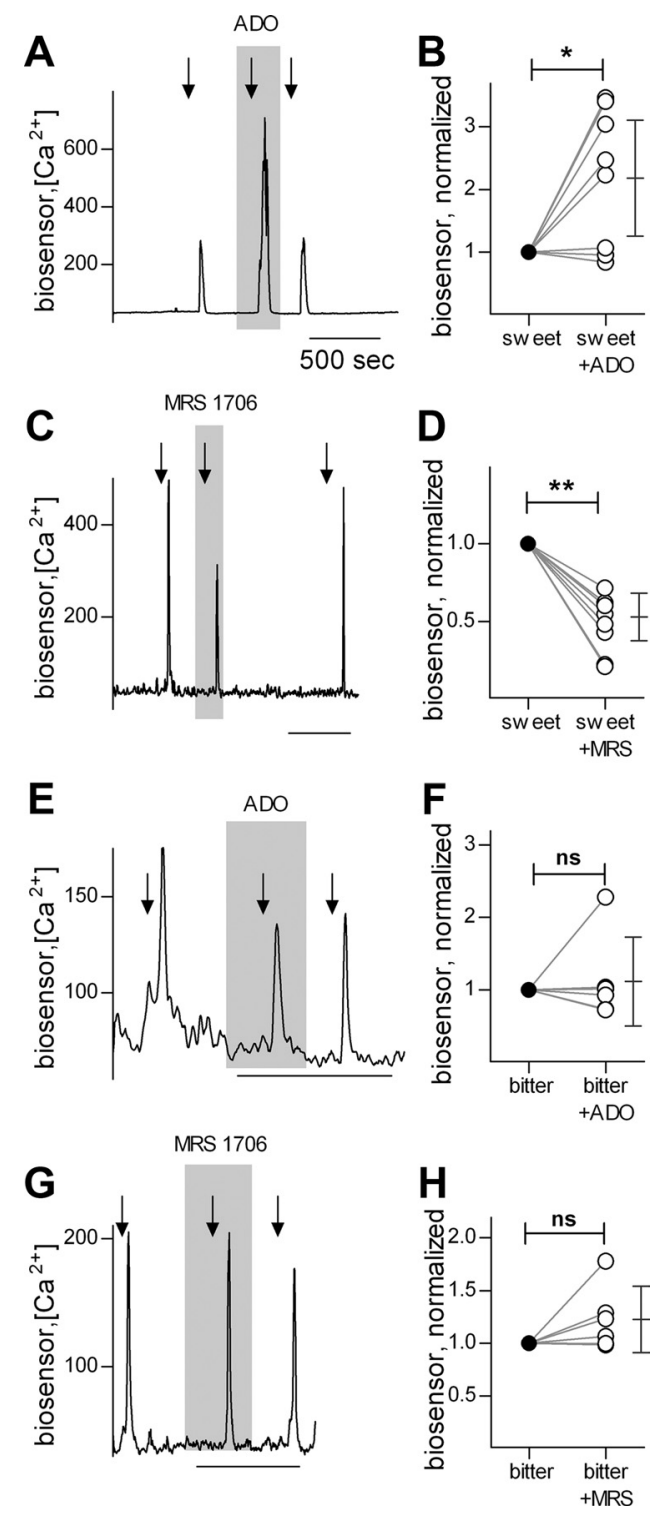

Figure 2. Taste-evoked transmitter (ATP) secretion from taste buds in response to sweet and bitter tastants, measured with biosensors. $A$, Traces show ATP biosensor responses evoked by stimulating the taste bud with a mixture of sweet compounds (arrows). Sweet-evoked ATP release is significantly enhanced by presence of adenosine in the bath ( $5 \mu \mathrm{M}$, shaded area). $\boldsymbol{B}$, Summary of sweet-evoked ATP release. ATP biosensor responses were normalized to the response before adenosine. ATP release after adenosine was significantly elevated $(p<0.02$, $n=8$ cells, Student's paired two-tailed $t$ test). Symbols on the right show the mean and $95 \%$ confidence interval. C, The A2B receptor antagonist, MRS 1706 ( $250 \mathrm{~nm}$, present throughout shaded area), reduces sweet-evoked ATP release, indicating that sweet taste stimulation produces endogenous adenosine. Traces and stimuli as in $\boldsymbol{A}$. $\boldsymbol{D}$, Summary of data from experiments as in $\boldsymbol{C}(p<0.01, n=8$ cells). $\boldsymbol{E}$, Adenosine has no effect on bitter-evoked ATP release. $\boldsymbol{F}$, Summary of bitter-evoked ATP release, as in $\boldsymbol{E}$ ( $p=0.64, n=6$ cells). $\boldsymbol{G}$, MRS 1706 has no effect on ATP release in response to bitter taste. $\boldsymbol{H}$, Summary of data showing effects of MRS 1706 on bitter-evoked ATP release ( $p=0.13, n=6$ cells). Calibrations in $\boldsymbol{C}, \boldsymbol{E}$, and $\boldsymbol{G}$ as in $\boldsymbol{A}$.

(also known as PAP). Using histochemical assays, we tested for the presence of these two catabolic activities in vallate taste papillae. Dorsal root ganglia (DRGs) served as positive controls and showed prominent activity for both NT5E and ACPP, as previously reported (Zylka et al., 2008; Sowa et al., 2010). In vallate papillae, there was strong histochemical staining for NT5E in non-taste surface epithelium, in keratinocytes surrounding taste buds, and in the connective tissue underlying taste epithelium (Fig. $3 A, C$ ). Nucleotidase activity was also detected within taste buds and appeared to reside in slender cells reminiscent of Presynaptic cells (Fig. 3C). In parallel assays on tissue from mutant mice lacking NT5E $\left(N t 5 e^{-l-}\right)$, there was a substantial loss of reaction product (Fig. $3 B, D$ ). Dorsal root ganglia served as controls with strong staining in the epineurium in wildtype but not in $N t 5 e^{-1-}$ mice (Fig. $3 E, F$ ).

As an independent test for the presence of NT5E in taste tissue, we used immunofluorescence staining for this nucleotidase. In vallate epithelium of wild-type mice, strong fluorescence was detected in both non-taste epithelial cells immediately surrounding taste buds and in underlying connective tissue (Fig. 3G). More modest staining was also apparent in a few slender cells in many taste buds. This pattern of immunofluorescence was very similar to the pattern of NT5E enzyme histochemical staining (Fig. $3 A, C$ ). Immunostaining for NT5E was completely lacking in tissue from $N t 5 e^{-1-}$ mice (Fig. $3 H$ ). When tissue from Gad1GFP mice was immunostained in the same manner, we noted that most of the NT5E-immunofluorescence within the taste bud was localized to GFP-positive cells (Fig. $3 I, J$ ). We have previously shown that in this transgenic strain, GFP is limited to the type III (Presynaptic) cells (Tomchik et al., 2007).

We also conducted histochemical staining under acidic conditions, which visualizes ACPP. In contrast to the pattern for NT5E, very little ACPP reaction product was detected in taste buds or in surrounding vallate tissue (Fig. $4 A, B$ ). We did detect robust histochemical staining for ACPP in the Von Ebner glands below taste epithelium (Fig. 4C) and in small and medium sized neurons in dorsal root ganglia (Fig. 4D). In aggregate, the pattern of histochemical staining suggests that NT5E is the predominant enzyme in taste buds that is responsible for generating adenosine from ATP.

\section{Adenosine receptors and enzymes that produce adenosine are expressed in taste buds}

To address the molecular basis for adenosine enhancement of sweet taste, we asked which adenosine receptors are present in taste tissue. Using RT-PCR, we tested for expression of Adora1, Adora2a, Adora2b and Adora3 which encode the adenosine receptors A1, A2A, A2B, and A3, respectively. Of these, only Adora $2 \mathrm{~b}$ was prominently expressed in vallate taste buds. Adora 1 showed only a faint signal under parallel conditions, suggesting that its expression level is substantially lower than that of Adora2b (Fig. 5A). We also detected a faint signal for Adora2b in non-taste epithelium. Adora2a and Adora3 were not detected in taste buds or in non-taste lingual epithelium.

Because physiological studies (Figs. 1, 2) had demonstrated that adenosine modulates taste signals for sweet but not bitter stimuli, we asked whether the expression of Adora2b was associated with particular taste receptors. We conducted single-cell RTPCR on 23 isolated Receptor cells (identified as GFP-positive cells from taste buds of PLCb2-GFP mice). Aliquots of each cell's cDNA were tested in parallel for Adora2b, the sweet taste receptor subunit, Tas1r2, and two bitter taste receptors, Tas2r105 and Tas2r108. The two bitter receptors were selected because they detect cycloheximide and denatonium, respectively (Chandrashekar et al., 2000), the stimuli used in our physiological analyses above. Our data indicate there is a positive association of Adora2b with Tas1r2 $(r=0.59, p=0.003)$, and a negative association with Tas2r105 $(r=-0.53, p=0.009)$ and Tas2r108 $(r=$ $-0.59, p=0.003$ ) (Fig. 5B).

We subsequently conducted RT-PCR on T7 linear-amplified RNA from isolated single taste cells. Each cell was classified according to the presence of transcripts for Ntpdase2, Plcb2 or Snap25, representing Glial-like (type I), Receptor (type II) or Presynaptic (type III) taste cells, respectively (DeFazio et al., 2006; Dvoryan- 

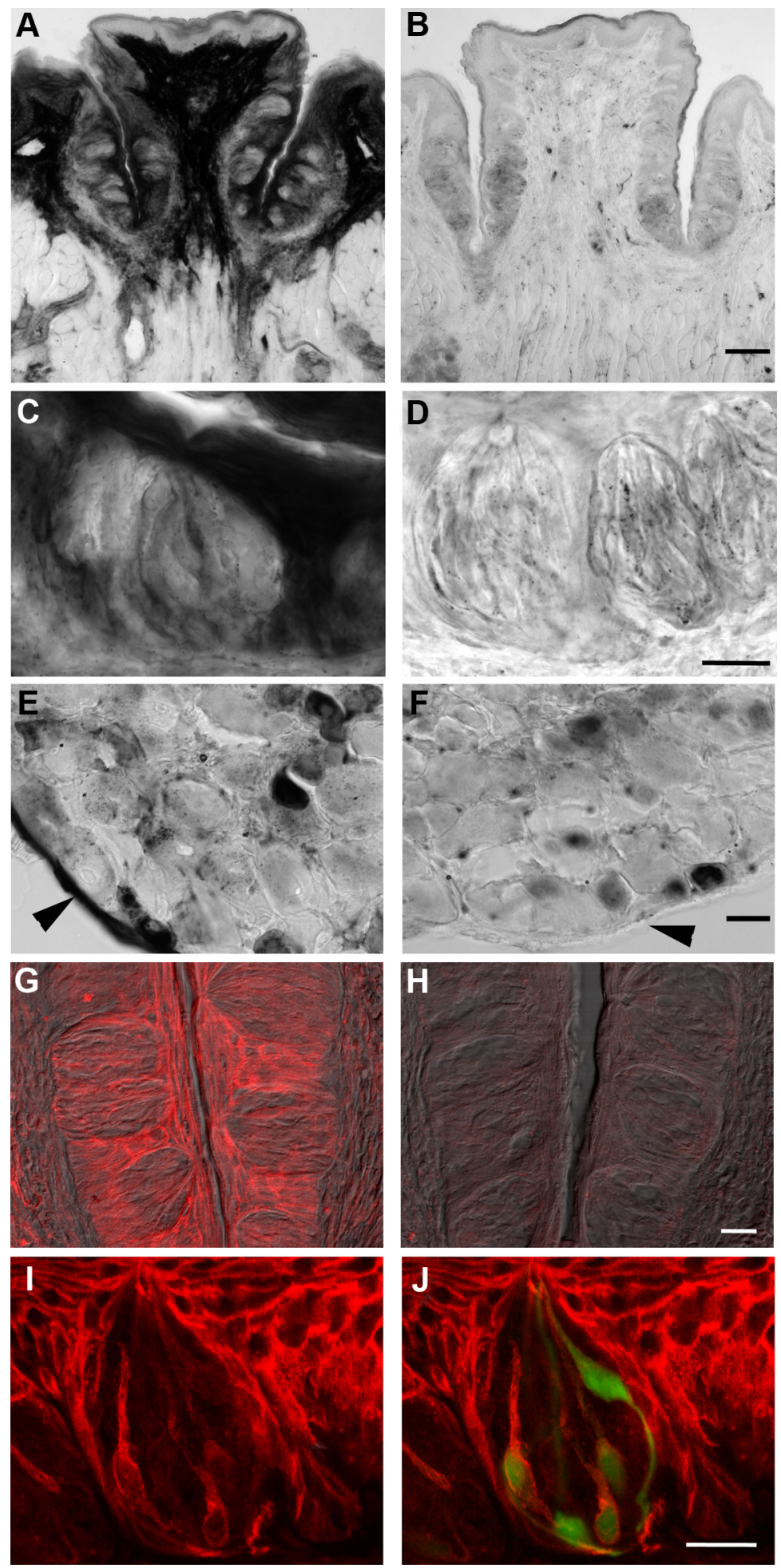

Figure 3. Enzyme histochemical and immunofluorescent localization of ecto-5'-nucleotidase, NT5E. A, Cryosection of wildtype vallate papilla, developed to reveal enzymatic conversion of AMP to adenosine at pH 7.0. Very strong enzymatic activity, seen as dark staining, is present in the connective tissue core of the papilla, in non-taste epithelium on the lingual surface, and in keratinocytes surrounding taste buds. $\boldsymbol{B}$, Cryosection of vallate papilla from a Nt5e ${ }^{-1-}$ mouse, stained in parallel with that in $\boldsymbol{A}$. Note the loss of prominent signal in the core of the papilla, in non-taste lingual epithelium, and in keratinocytes surrounding taste buds. C, At higher magnification, taste buds from wild-type mice can be seen to contain NT5E activity, particularly in slender cells. D, Higher magnification of taste buds from $N t 5 e^{-1-}$ mouse. No distinct reaction product is seen in cells, although faint residual staining appears throughout the epithelium and taste buds. E, Dorsal root ganglion from wild-type mouse as in $A$ and $($ shows that small- and medium-sized neurons, and the epineurium (arrowhead) of the ganglion, are stained for NT5E. F, Dorsal root ganglion from the same $\mathrm{NtSe}^{-1-}$ mouse as in $\boldsymbol{B}$ and $\boldsymbol{D}$ above shows that there is no staining in epineurium (arrowhead), but nucleotidase activity remains in small neurons, consistent with previous results (Sowa etal., 2010). G, Immunofluorescence for NT5E in vallate papilla of wild-type mouse, showing pronounced staining in keratinocytes surrounding the taste buds, and more modest staining in limited chikov et al., 2009) (Fig. 6A). The distinction of 3 separate classes of taste bud cells (for review, see Chaudhari and Roper, 2010) was revalidated in the present analyses by the observation that 0 of 87 cells expressed more than one of these three diagnostic markers. Amplified RNAs from 12 cells of each type (total, 36 cells) were then selected for further analysis. Consistent with its prominent expression in vallate taste buds (Fig. $5 A$ ), Adora $2 b$ was found in $25 \%$ of all 36 taste cells. Significantly, 7 of 9 Adora2bpositive cells were Receptor (type II) cells (Fig. 6B). Adoral was also detected, but only in one Receptor cell. We did not observe any receptors for adenosine in Presynaptic (type III) cells, consistent with the lack of physiological responses of these cells to the nucleoside.

Next, we asked which of the taste G-protein-coupled taste receptors were expressed in cells that also expressed A2B receptors. We tested the amplified RNA single-cell samples for Tas1r1, Tas1r2 and Tas1r3, that is, subunits of sweet and umami taste receptors. We also tested for Tas2r105, a bitter taste receptor that detects cycloheximide (Chandrashekar et al., 2000), one of the stimuli used in the functional experiments of Figures 1 and 2 . As expected, expression of the taste receptors was detected in Receptor cells (10 of 12 cells) and only in this class of cells (Fig. 6B). The presence of Adora $2 \mathrm{~b}$ was strongly associated with the presence of Tas1r2, a subunit of the sweet taste receptor $(r=0.77, p<$ 0.001 across all three cell types, $n=36$; and within Receptor cells only, $r=0.84, p=$ $0.001, n=12$ ). There was no association of Adora2b with either Tas1r1, an umami receptor subunit, or Tas $2 \mathrm{r} 5$, a bitter receptor (in both cases, $p>0.05$ ). These observations are entirely consistent with our finding that adenosine modulates the sensitivity of and transmitter release from sweet-transducing cells, but not of bitter- and perhaps also umami-sensitive cells.

Last, we investigated the amplified RNA taste cell samples for expression of enzymes

$\leftarrow$

numbers of slender taste cells. Image is a merge of immunofluorescence (red) and Nomarski differential contrast optics. $\boldsymbol{H}$, Sections of vallate papilla from $N t 5 e^{-/-}$mouse, stained in parallel and photographed with identical settings as in $\mathbf{G}$. No signal is detected either in epithelium or in taste cells. $\boldsymbol{I}, \boldsymbol{J}$, Higher magnification of a vallate taste bud from a Gad1-GFP mouse stained for NT5E. The merged view (J) shows that NT5E signal (red) within the taste bud is in slender, GFP-positive cells (i.e., Type III/Presynaptic cells). Note how NT5E immunostaining $(I, J)$ is similar to the shape and incidence of NT5E histochemical reaction product (C). Scale bars: $\boldsymbol{A}, \boldsymbol{D}, 100 \mu \mathrm{m}$; $\boldsymbol{B}, \boldsymbol{E}, 20 \mu \mathrm{m} ; \boldsymbol{C}, \boldsymbol{F}, 25 \mu \mathrm{m} ; \boldsymbol{G}, \boldsymbol{H}, 20 \mu \mathrm{m} ; \boldsymbol{I}, \boldsymbol{J}, 20 \mu \mathrm{m}$. 

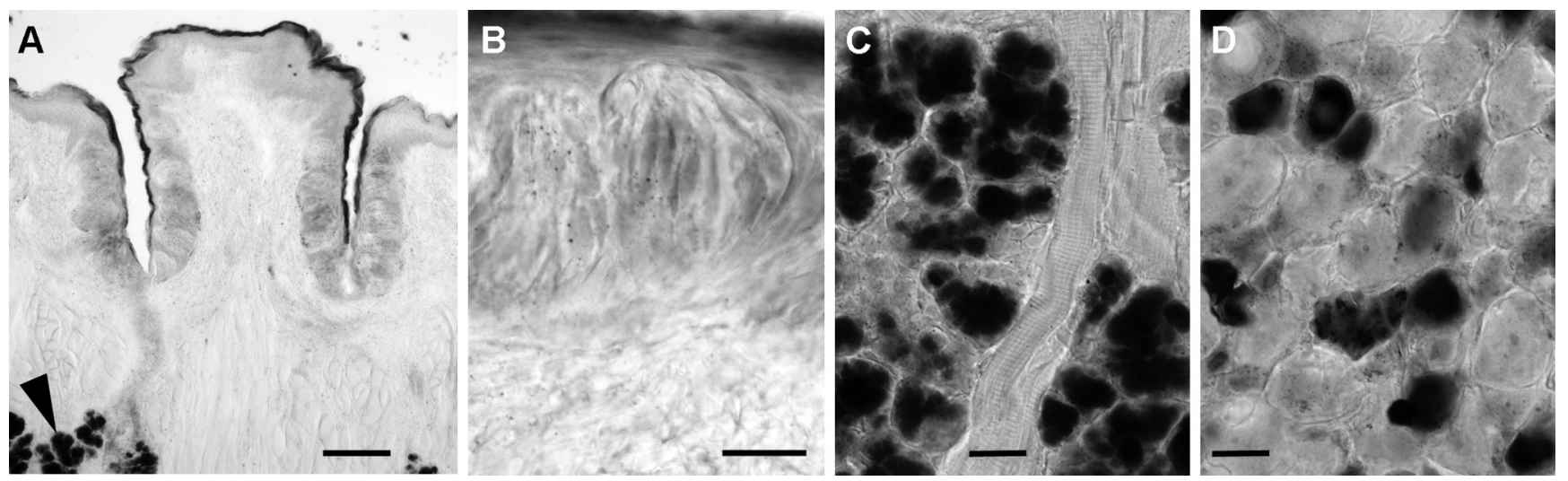

Figure 4. Enzyme histochemical detection of acid phosphatase activity. $A$, Cryosection of wild-type vallate papilla, developed to reveal enzymatic conversion of AMP to adenosine at pH 5.6. The enzymatic reaction conditions are optimized to detect ACPP. Only faint signal is detectable throughout the tissue with the exception of von Ebner glands located deep in the tissue (arrowhead). $\boldsymbol{B}$, At higher magnification, reaction product is detected at low levels in the taste bud although individual cells cannot readily be distinguished. C, Von Ebner glands below taste epithelium show prominent signal in acini. $\boldsymbol{D}$, Dorsal root ganglion from the same wild-type mouse as in $\boldsymbol{A}$ shows some small and medium sized neurons are positive for the acid phosphatase, while large neurons and the epineurium are negative. Scale bars: $\boldsymbol{A}, 100 \mu \mathrm{m} ; \boldsymbol{B}, 20 \mu \mathrm{m} ; \boldsymbol{C}, \boldsymbol{D}, 25 \mu \mathrm{m}$.

A
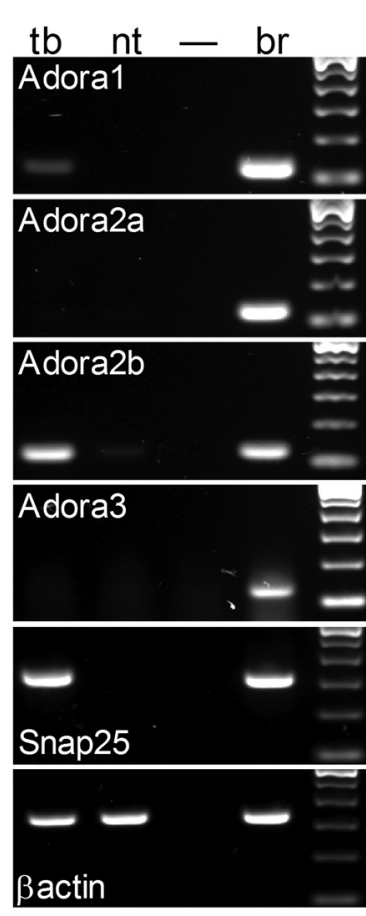

B

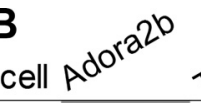

$<25^{11^{2}}$

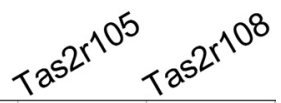

\begin{tabular}{|l|}
\hline 1 \\
\hline 2 \\
\hline 3 \\
\hline 4 \\
\hline 5 \\
\hline 6 \\
\hline 7 \\
\hline
\end{tabular}

\begin{tabular}{|c|}
\hline 1 \\
\hline 2 \\
\hline 3 \\
\hline 4 \\
\hline 5 \\
\hline 6 \\
\hline 7 \\
\hline 8 \\
\hline 9 \\
\hline 10 \\
\hline 11 \\
\hline 12 \\
\hline 13 \\
\hline
\end{tabular}

\section{3}

\begin{tabular}{|l|l|l|}
\hline 13 & & \\
\hline 14 & & \\
\hline 15 & & \\
\hline
\end{tabular}

\begin{tabular}{|l|l|l|}
\hline 15 & \\
\hline 16 & & \\
\hline 17 & & \\
\hline 18 & & \\
\hline 19 & & \\
\hline 20 & & \\
\hline 21 & \\
\hline 22 & & \\
\hline 23 & & \\
\hline & & \\
\hline
\end{tabular}

RT-
Figure 5. Adenosine receptor Adora2b is associated with Tas1r2, a sweet taste receptor subunit in taste cells. A, RT-PCR on isolated vallate taste buds (tb) and non-taste lingual epithelium (nt) reveals prominent expression of Adora2b and lower levels of Adora 1 in taste buds. Neither Adora2a nor Adora3 were detected. Positive and negative controls run in parallel included brain (br) and $\mathrm{H}_{2} \mathrm{O}$ in place of template (-). RT-PCR for Snap25 served as a positive control for taste buds. B, Single-cell RT-PCR on 23 individual GFP-positive cells (i.e., Type II Receptor cells) from taste buds of PIcb2-GFP mice. Aliquots (20\%) of each cell's cDNA were tested for Adora2b, one sweet receptor subunit (Tas1r2) and two bitter receptors (Tas2r105, Tas2r108). One cell (RT-) was processed without reverse transcriptase, and yielded no PCR products.

that produce extracellular adenosine. As discussed above (Figs. 3, 4), enzymes that commonly convert extracellular AMP to adenosine include NT5E, and ACPP. The latter enzyme exists as secreted and membrane-bound isoforms that are derived from two different splice variants (Quintero et al., 2007). Hence, we performed RT-PCR using splice variant-specific primers and determined that only the transmembrane (longer) isoform is expressed in taste buds (data not shown). We then tested for expression of both
Nt5e and Acpp genes in the same panel of 36 isolated single taste cells, above. Transcripts for at least one of the enzymes were detected in 11 of 12 Presynaptic cells (Fig. 6B). In 8 of the 12 Presynaptic cells, there was overlapping expression of $N t 5 e$ and Acpp, similar to the reported coexpression of these enzymes in small and medium DRG sensory neurons (Sowa et al., 2010). In contrast, no Receptor cells and only 3 of 12 type I cells expressed either adenosine-producing enzyme. None of the taste cells showed coexpression of adenosine receptors and catabolic enzymes. In short, the AMP-degrading enzymes, NT5E and ACPP are both expressed in taste buds, predominantly in Presynaptic (type III) taste cells, providing a mechanism for generating adenosine during taste reception and a molecular basis for the above histochemical findings.

\section{Discussion}

Our data clearly indicate that adenosine has selective actions on sweet taste mechanisms within the taste bud. Specifically, we show that adenosine enhances sweetevoked $\mathrm{Ca}^{2+}$ responses and increases sweet-evoked taste transmitter (ATP) release. We did not observe this modulatory effect of adenosine on bitter taste. Regarding umami taste, we did not investigate ATP transmitter release because of the known presence of basolateral (non-taste) receptors for glutamate on many taste cells (Caicedo et al., 2000; Vandenbeuch et al., 2010) and because inosine (derived by hydrolysis of the umami stimulus, IMP) activates certain adenosine receptors (Fredholm, 2010). Hence, applying umami tastants (i.e., glutamate, $5^{\prime}$-IMP) to isolated taste buds would likely activate nontaste receptors, compromising interpretation.

During taste excitation, adenosine would be formed by NT5Emediated catabolism of AMP, itself derived from ATP. The selec- 
A

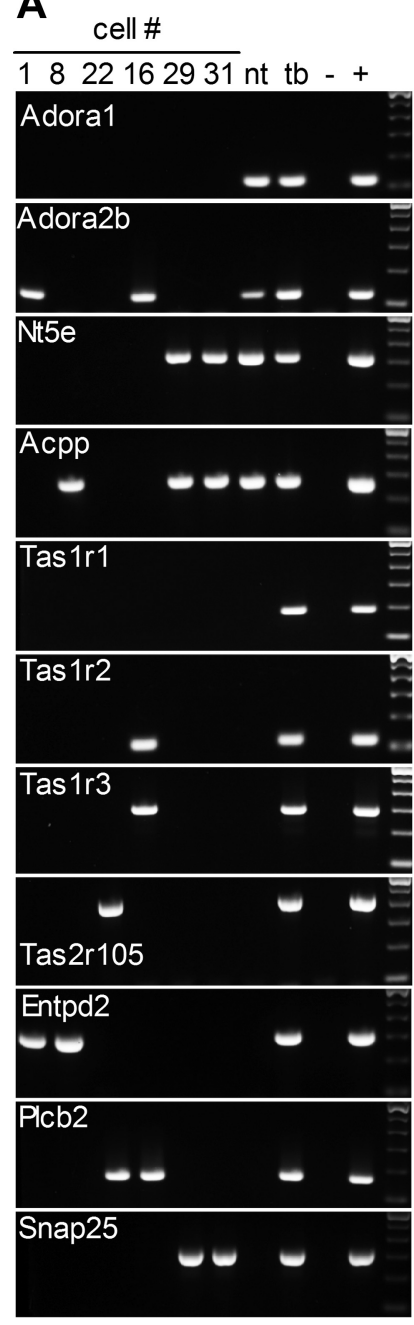

B

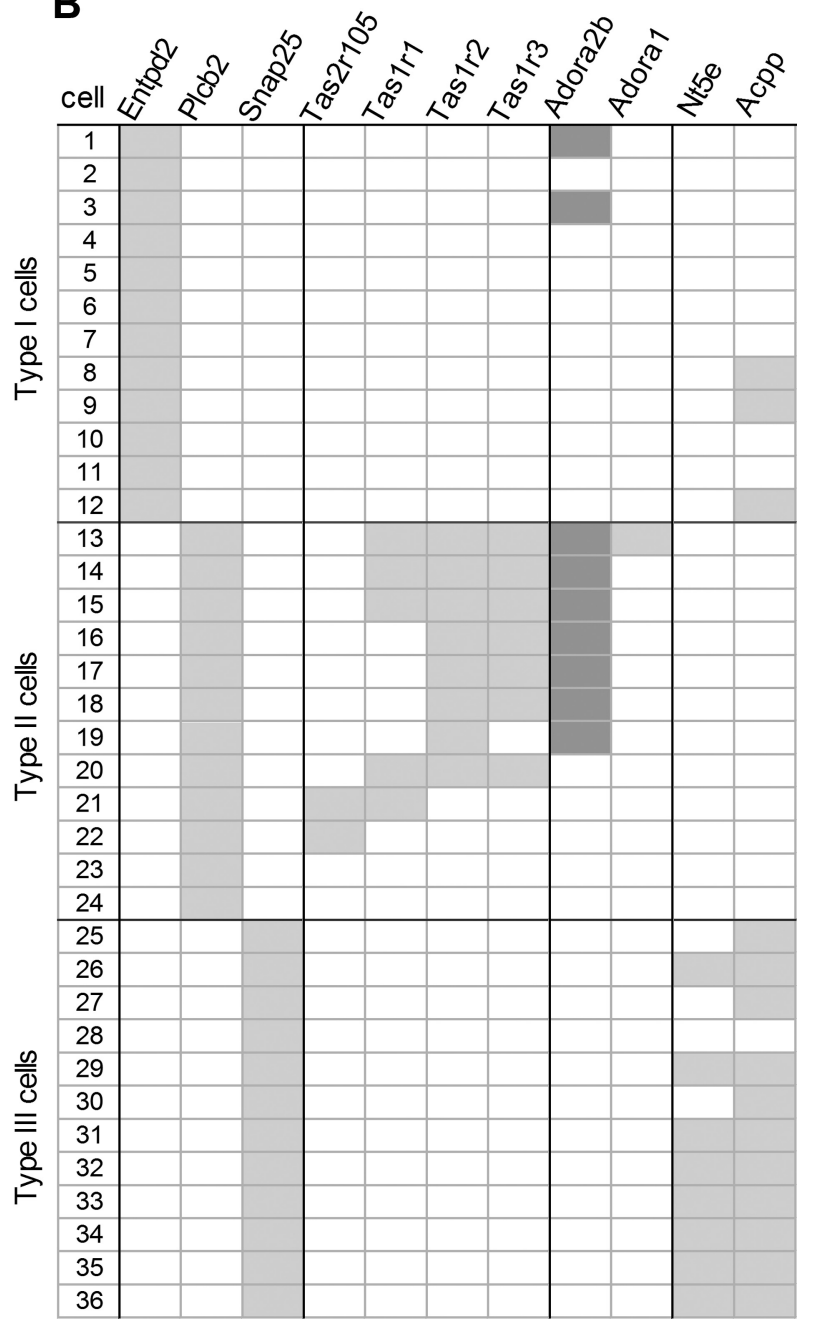

Figure 6. Adora2b receptor is associated with taste cells that express the sweet taste receptor subunit, Tas $1 \mathrm{r} 2$. T7-linear RNA amplification was performed on 36 individually isolated taste cells, followed by RT-PCR to classify cells into one of three cell types according to expression of the diagnostic mRNAs: Entpd2 (type I), PIc $\beta 2$ (type II) and Snap25 (type III). $\boldsymbol{A}$, Two exemplar cells for each cell type are shown; each column contains data from a single cell. Each cell was also tested for expression of taste receptors, Tas2r105, Tas1r1, Tas1r2, and Tas1r3; of adenosine receptors, Adora1 and Adora2b; and of catabolicenzymes that produce adenosine, Nt5e and Acpp. To the right of individual cells are cDNAs from non-taste lingual epithelium ( $n$ t), isolated taste buds (tb), and a positive control ( + ) — either brain forthe top $4 \mathrm{gels}$ (adenosine receptors and enzymes), or vallate taste epithelium for the bottom $7 \mathrm{gels}$ (taste receptors and diagnostic markers); parallel negative control reaction ( - ) without cDNA template. $\boldsymbol{B}$, Aggregate data from all 36 taste cells. Adora2b is prominently detected in cells expressing Tas1r2 (i.e., sweet taste cells). Enzymes that convert AMP to adenosine (Nt5e and Acpp) were primarily in Presynaptic (type III) taste cells.

tive effect on sweet taste derives from expression of adenosine A2B receptors primarily on T1R2-expressing (i.e., sweet-sensing) Receptor cells. In brief, adenosine is a naturally occurring autocrine modulator for sweet taste. These data are entirely consistent with the preliminary findings of Kataoka and Finger (2008) showing adenosine $\mathrm{A} 2 \mathrm{~B}$ receptors in taste buds, and help explain the preliminary demonstration by Kinnamon et al. (2011) that A2B-knock-out mice have depressed sweet-evoked afferent signals.

Our single-cell amplified RNA-based profiling data suggest widespread expression of the Tas1r2 mRNA in many Receptor cells in vallate taste buds. Indeed, a similar incidence was reported for mouse vallate taste cells based on single-cell RT-PCR data (Tizzano et al., 2008). Our result on the occasional coexpression of Tas1r1, Tas1r2, and Tas1r3 mRNAs in a small fraction of vallate taste cells is consistent with earlier observations made using in situ hybridization (Hoon et al., 1999; Stone et al., 2007). Indeed, an overlapping pattern of T1R1, T1R2 and T1R3 taste receptors may underlie the dual sweet and umami responsivity observed in Receptor cells of taste buds (Niki et al., 2011).
Autocrine and paracrine interactions that modulate taste bud signaling and that involve ATP, serotonin, and GABA have been recently characterized (Huang et al., 2007, 2009; Dvoryanchikov et al., 2011). We now show that cell-cell interactions in taste buds also involve adenosine. Taste buds have many parallels with the enteric nervous system. Adenosine has been known to play a role in the intestine for $>60$ years (Ewing et al., 1949) and high levels of A2B receptors are found in the intestine (Stehle et al., 1992). Chemosensory neurons of the enteric nervous system are sensitized by adenosine acting on A2 receptors (Christofi et al., 2001). The release of serotonin from chemosensory enterochromaffin cells of intestinal crypts, which modulates smooth muscle contractions is under the control of excitatory (A2) and inhibitory (A1) adenosine receptors (Christofi, 2008). Thus, adenosine may modulate chemosensitivity and neurotransmitter release in taste buds much as it does in the intestine. Another chemosensory organ, the carotid body, also expresses high levels of adenosine receptors and adenosine activates its chemosensory cells (McQueen and Ribeiro, 1981, 1983). Thus, 
adenosine-mediated modulation may comprise a mechanism that is preserved across multiple chemosensory organs.

Adenosine A2 receptors enhance the release of acetylcholine and glutamate in the rat cerebral cortex (O'Regan et al., 1992; Phillis et al., 1993). GABA release in the rat globus pallidus and noradrenaline release from the epididymal vas deferens of the rat were also enhanced by A2B adenosine receptors (Goncalves and Queiroz, 1993; Mayfield et al., 1993). Cunha et al. (1994) suggested that differential expression of inhibitory A1 receptors and excitatory A2 receptors in the same cells could provide a finetuning mechanism for regulating neurotransmitter release. Interestingly, we found both adenosine $\mathrm{A} 1$ and $\mathrm{A} 2 \mathrm{~B}$ receptors in a minority of sweet-sensitive taste bud cells.

Our data indicate that NT5E is a prominent enzyme in taste buds for degrading ATP to adenosine, although a lower level of ACPP was also present. In addition to the catabolic production of adenosine as an extracellular modulator, adenosine can also be released via equilibrative nucleoside transporters in some tissues (Baldwin et al., 2004). We did not explore this alternative source of adenosine in our present study. There are precedents in nociceptors for both NT5E and ACPP expression in the same cells (Suran, 1974; Sowa et al., 2010). The expression of NT5E and ACPP in Presynaptic (type III) taste cells presents an intriguing multicellular pathway for the formation of adenosine in taste buds. ATP is initially released from Receptor (type II) taste cells, and is degraded to ADP and AMP through the action of NTPDases on the surface of type I cells (Bartel et al., 2006). Subsequently, AMP is degraded to adenosine by Presynaptic (type III) cell ectonucleotidases (NT5E/ACPP). Finally, adenosine acts on sweet-sensitive Receptor (type II cells).

A comparable autocrine role for ATP and ADP acting on Receptor cells has previously been described, though not characterized for sweet-, bitter-, or umami-sensitive taste cells (Huang et al., 2009). Aside from neural tissues, adenosine receptor signaling is also important in many epithelia, where it is reported to either enhance proliferation or induce apoptosis, depending on which receptor is expressed (Merighi et al., 2002). Adenosine is commonly delivered to many epithelial cells, including keratinocytes, via the action on the neutral ectonucleotidase, NT5E (Strohmeier et al., 1997; Thompson et al., 2004; Sowa et al., 2010).

There is a circadian variation in plasma adenosine levels in the human circulatory system (Feldberg and Sherwood, 1954; Haulică et al., 1973; Dunwiddie and Worth, 1982). As the day progresses, plasma adenosine levels steadily increase until the subject sleeps. Once fully rested, plasma adenosine falls to baseline values and begins to steadily increase throughout the new day. Sleepiness is attributed in part to the inhibitory effects of A1 adenosine receptors (Elmenhorst et al., 2007). Caffeine, an adenosine $\mathrm{A} 1$ receptor antagonist, temporarily inhibits sleepiness. It is intriguing to speculate that diurnal variations in sweet taste sensitivity previously attributed to circulating leptin (Kant and Bauman, 1993; Nakamura et al., 2008) may be at least partially attributed to circadian plasma adenosine levels.

\section{References}

Baldwin SA, Beal PR, Yao SY, King AE, Cass CE, Young JD (2004) The equilibrative nucleoside transporter family, SLC29. Pflugers Arch 447:735-743.

Bartel DL, Sullivan SL, Lavoie EG, Sévigny J, Finger TE (2006) Nucleoside triphosphate diphosphohydrolase-2 is the ecto-ATPase of type I cells in taste buds. J Comp Neurol 497:1-12.

Caicedo A, Jafri MS, Roper SD (2000) In situ $\mathrm{Ca}^{2+}$ imaging reveals neurotransmitter receptors for glutamate in taste receptor cells. J Neurosci 20:7978-7985.
Chandrashekar J, Mueller KL, Hoon MA, Adler E, Feng L, Guo W, Zuker CS, Ryba NJ (2000) T2Rs function as bitter taste receptors. Cell 100:703-711.

Chattopadhyaya B, Di Cristo G, Higashiyama H, Knott GW, Kuhlman SJ, Welker E, Huang ZJ (2004) Experience and activity-dependent maturation of perisomatic GABAergic innervation in primary visual cortex during a postnatal critical period. J Neurosci 24:9598-9611.

Chaudhari N, Roper SD (2010) The cell biology of taste. J Cell Biol 190:285-296.

Christofi FL (2008) Purinergic receptors and gastrointestinal secretomotor function. Purinergic Signal 4:213-236.

Christofi FL, Zhang H, Yu JG, Guzman J, Xue J, Kim M, Wang YZ, Cooke HJ (2001) Differential gene expression of adenosine A1, A2a, A2b, and A3 receptors in the human enteric nervous system. J Comp Neurol 439:46-64.

Cunha RA, Milusheva E, Vizi ES, Ribeiro JA, Sebastião AM (1994) Excitatory and inhibitory effects of $\mathrm{A} 1$ and $\mathrm{A} 2 \mathrm{~A}$ adenosine receptor activation on the electrically evoked $\left[{ }^{3} \mathrm{H}\right]$ acetylcholine release from different areas of the rat hippocampus. J Neurochem 63:207-214.

Dando R, Roper SD (2009) Cell-to-cell communication in intact taste buds through ATP signalling from pannexin 1 gap junction hemichannels. J Physiol 587:5899-5906.

DeFazio RA, Dvoryanchikov G, Maruyama Y, Kim JW, Pereira E, Roper SD, Chaudhari N (2006) Separate populations of receptor cells and presynaptic cells in mouse taste buds. J Neurosci 26:3971-3980.

Dunwiddie TV, Worth T (1982) Sedative and anticonvulsant effects of adenosine analogs in mouse and rat. J Pharmacol Exp Ther 220:70-76.

Dvoryanchikov G, Sinclair MS, Perea-Martinez I, Wang T, Chaudhari N (2009) Inward rectifier channel, ROMK, is localized to the apical tips of glial-like cells in mouse taste buds. J Comp Neurol 517:1-14.

Dvoryanchikov G, Huang YA, Barro-Soria R, Chaudhari N, Roper SD (2011) GABA, its receptors, and GABAergic inhibition in mouse taste buds. J Neurosci 31:5782-5791.

Elmenhorst D, Meyer PT, Winz OH, Matusch A, Ermert J, Coenen $\mathrm{HH}$, Basheer R, Haas HL, Zilles K, Bauer A (2007) Sleep deprivation increases $\mathrm{A} 1$ adenosine receptor binding in the human brain: a positron emission tomography study. J Neurosci 27:2410-2415.

Ewing PL, Schlenk F, Emerson GA (1949) Comparison of smooth muscle effects of crotonoside (isoguanosine) and adenosine. J Pharmacol Exp Ther 97:379-383.

Feldberg W, Sherwood SL (1954) Injections of drugs into the lateral ventricle of the cat. J Physiol 123:148-167.

Finger TE, Danilova V, Barrows J, Bartel DL, Vigers AJ, Stone L, Hellekant G, Kinnamon SC (2005) ATP signaling is crucial for communication from taste buds to gustatory nerves. Science 310:1495-1499.

Fredholm BB (2010) Adenosine receptors as drug targets. Exp Cell Res 316:1284-1288.

Goncalves J, Queiroz G (1993) Facilitatory and inhibitory modulation by endogenous adenosine of noradrenaline release in the epididymal portion of rat vas deferens. Naunyn Schmiedebergs Arch Pharmacol 348:367-371.

Grynkiewicz G, Poenie M, Tsien RY (1985) A new generation of $\mathrm{Ca}^{2+}$ indicators with greatly improved fluorescence properties. J Biol Chem 260:3440-3450

Haulică I, Ababei L, Brănisteanu D, Topoliceanu F, Busuioc A (1973) Preliminary data on the possible hypnogenic role of adenosine. Rev Roum Physiol 10:275-279.

Herness S, Zhao FL, Kaya N, Lu SG, Shen T, Sun XD (2002) Adrenergic signalling between rat taste receptor cells. J Physiol 543:601-614.

Hoon MA, Adler E, Lindemeier J, Battey JF, Ryba NJ, Zuker CS (1999) Putative mammalian taste receptors: a class of taste-specific GPCRs with distinct topographic selectivity. Cell 96:541-551.

Huang YA, Dando R, Roper SD (2009) Autocrine and paracrine roles for ATP and serotonin in mouse taste buds. J Neurosci 29:13909-13918.

Huang YJ, Maruyama Y, Lu KS, Pereira E, Plonsky I, Baur JE, Wu D, Roper SD (2005) Mouse taste buds use serotonin as a neurotransmitter. J Neurosci 25:843-847.

Huang YJ, Maruyama Y, Dvoryanchikov G, Pereira E, Chaudhari N, Roper SD (2007) The role of pannexin 1 hemichannels in ATP release and cell-cell communication in mouse taste buds. Proc Natl Acad Sci U S A 104:6436-6441.

Kant GJ, Bauman RA (1993) Effects of chronic stress and time of day on preference for sucrose. Physiol Behav 54:499-502.

Kataoka S, Finger TE (2008) Expression of adenosine receptors in mouse taste buds. Chem Senses 33:S128. 
Kawai K, Sugimoto K, Nakashima K, Miura H, Ninomiya Y (2000) Leptin as a modulator of sweet taste sensitivities in mice. Proc Natl Acad Sci U S A 97:11044-11049.

Kim JW, Roberts C, Maruyama Y, Berg S, Roper S, Chaudhari N (2006) Faithful expression of GFP from the PLCbeta2 promoter in a functional class of taste receptor cells. Chem Senses 31:213-219.

Kinnamon SC, Baquero A, Katoaka S, Shultz N, Finger TE (2011) The A2B adenosine receptor is required for sweet taste in posterior tongue. Chem Senses 36:A27 (abstr.).

Kukulski F, Lévesque SA, Sévigny J (2011) Impact of ectoenzymes on p2 and p1 receptor signaling. Adv Pharmacol 61:263-299.

Mayfield RD, Suzuki F, Zahniser NR (1993) Adenosine A2a receptor modulation of electrically evoked endogenous GABA release from slices of rat globus pallidus. J Neurochem 60:2334-2337.

McQueen DS, Ribeiro JA (1981) Effect of adenosine on carotid chemoreceptor activity in the cat. Br J Pharmacol 74:129-136.

McQueen DS, Ribeiro JA (1983) On the specificity and type of receptor involved in carotid body chemoreceptor activation by adenosine in the cat. Br J Pharmacol 80:347-354.

Merighi S, Mirandola P, Milani D, Varani K, Gessi S, Klotz KN, Leung E, Baraldi PG, Borea PA (2002) Adenosine receptors as mediators of both cell proliferation and cell death of cultured human melanoma cells. J Invest Dermatol 119:923-933.

Nakamura Y, Sanematsu K, Ohta R, Shirosaki S, Koyano K, Nonaka K, Shigemura N, Ninomiya Y (2008) Diurnal variation of human sweet taste recognition thresholds is correlated with plasma leptin levels. Diabetes 57:2661-2665.

Niki M, Takai S, Kusuhara Y, Ninomiya Y, Yoshida R (2011) Responses to apical and basolateral application of glutamate in mouse fungiform taste cells with action potentials. Cell Mol Neurobiol 31:1033-1040.

Ogura T (2002) Acetylcholine increases intracellular $\mathrm{Ca}^{2+}$ in taste cells via activation of muscarinic receptors. J Neurophysiol 87:2643-2649.

O’Regan MH, Simpson RE, Perkins LM, Phillis JW (1992) Adenosine receptor agonists inhibit the release of gamma-aminobutyric acid (GABA) from the ischemic rat cerebral cortex. Brain Res 582:22-26.

Phillis JW, O’Regan MH, Perkins LM (1993) Effect of adenosine receptor agonists on spontaneous and $\mathrm{K}(+)$-evoked acetylcholine release from the in vivo rat cerebral cortex. Brain Res 605:293-297.

Pumplin DW, Yu C, Smith DV (1997) Light and dark cells of rat vallate taste buds are morphologically distinct cell types. J Comp Neurol 378:389-410.

Quintero IB, Araujo CL, Pulkka AE, Wirkkala RS, Herrala AM, Eskelinen EL, Jokitalo E, Hellström PA, Tuominen HJ, Hirvikoski PP, Vihko PT (2007) Prostatic acid phosphatase is not a prostate specific target. Cancer Res 67:6549-6554.
Romanov RA, Rogachevskaja OA, Bystrova MF, Jiang P, Margolskee RF, Kolesnikov SS (2007) Afferent neurotransmission mediated by hemichannels in mammalian taste cells. EMBO J 26:657-667.

Shin YK, Martin B, Golden E, Dotson CD, Maudsley S, Kim W, Jang HJ, Mattson MP, Drucker DJ, Egan JM, Munger SD (2008) Modulation of taste sensitivity by GLP-1 signaling. J Neurochem 106:455-463.

Sowa NA, Taylor-Blake B, Zylka MJ (2010) Ecto-5'-nucleotidase (CD73) inhibits nociception by hydrolyzing AMP to adenosine in nociceptive circuits. J Neurosci 30:2235-2244.

Sperlágh B, Vizi ES (2011) The role of extracellular adenosine in chemical neurotransmission in the hippocampus and basal ganglia: pharmacological and clinical aspects. Curr Top Med Chem 11:1034-1046.

Stehle JH, Rivkees SA, Lee JJ, Weaver DR, Deeds JD, Reppert SM (1992) Molecular cloning and expression of the cDNA for a novel A2-adenosine receptor subtype. Mol Endocrinol 6:384-393.

Stone LM, Barrows J, Finger TE, Kinnamon SC (2007) Expression of T1Rs and gustducin in palatal taste buds of mice. Chem Senses 32:255-262.

Streitová D, Sefc L, Savvulidi F, Pospísil M, Holá J, Hofer M (2010) Adenosine $\mathrm{A}(1), \mathrm{A}(2 \mathrm{a}), \mathrm{A}(2 \mathrm{~b})$, and $\mathrm{A}(3)$ receptors in hematopoiesis. 1. Expression of receptor mRNA in four mouse hematopoietic precursor cells. Physiol Res 59:133-137.

Strohmeier GR, Lencer WI, Patapoff TW, Thompson LF, Carlson SL, Moe SJ, Carnes DK, Mrsny RJ, Madara JL (1997) Surface expression, polarization, and functional significance of CD73 in human intestinal epithelia. J Clin Invest 99:2588-2601.

Suran AA (1974) 5'-Nucleotidase and acid phosphatase of spinal cord. Quantitative histochemistry in cat and mouse spinal cords and in mouse brain. J Histochem Cytochem 22:812-818.

Thompson LF, Eltzschig HK, Ibla JC, Van De Wiele CJ, Resta R, MoroteGarcia JC, Colgan SP (2004) Crucial role for ecto-5'-nucleotidase (CD73) in vascular leakage during hypoxia. J Exp Med 200:1395-1405.

Tizzano M, Dvoryanchikov G, Barrows JK, Kim S, Chaudhari N, Finger TE (2008) Expression of Galpha14 in sweet-transducing taste cells of the posterior tongue. BMC Neurosci 9:110.

Tomchik SM, Berg S, Kim JW, Chaudhari N, Roper SD (2007) Breadth of tuning and taste coding in mammalian taste buds. J Neurosci 27:10840-10848.

Vandenbeuch A, Tizzano M, Anderson CB, Stone LM, Goldberg D, Kinnamon SC (2010) Evidence for a role of glutamate as an efferent transmitter in taste buds. BMC Neurosci 11:77.

Zylka MJ, Sowa NA, Taylor-Blake B, Twomey MA, Herrala A, Voikar V, Vihko P (2008) Prostatic acid phosphatase is an ectonucleotidase and suppresses pain by generating adenosine. Neuron 60:111-122. 